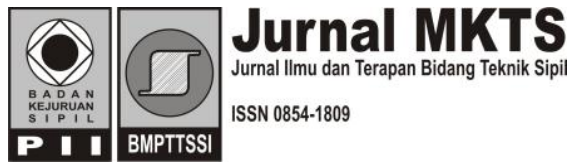

\title{
Analisis Tingkat Kepuasan Konsumen terhadap Pelayanan Bongkar- Muat Barang pada Terminal Petikemas Semarang
}

\author{
Yoeli Janto \\ Sekolah Tinggi Maritim dan Transpor AMNI \\ Jl. Soekarno-Hatta No.180, Pedurungan, Kota Semarang 50246 \\ E-mail: yoelijanto@yahoo.com
}

\begin{abstract}
This study aims to analyze the level of consumer expectations and service performance and user satisfaction level loading service at Semarang Container Terminal. It also analyzes the factors that must be maintained, high priority, low priority and customer satisfaction excessive loading and unloading of goods at the Container Terminal in Semarang. The samples are 73 respondents (companies) with data analysis using the Important Performance Analysis (IPA). Based on the analysis Cartesian diagram is known that factors that are considered important in accordance with the reality perceived by the customer so that there is a relatively high level of satisfaction on factors clarity services officer, disciplinary service officer, justice of service and comfort environment. While the factors that are considered less important by the customer and in fact not too special in which an increase in attributes in this quadrant can be reconsidered as an influence on the perceived benefits by a very small customer service is the factor procedures, responsibilities attendant service, speed of service and courtesy and hospitality workers.
\end{abstract}

Keywords: Optimization, Project scheduling.

\begin{abstract}
Abstrak
Penelitian ini bertujuan untuk menganalisis tingkat harapan konsumen dan kinerja layanan serta tingkat kepuasan pengguna jasa bongkar muat pada Terminal Petikemas Semarang. Selain itu juga menganalisis faktor yang harus dipertahankan, prioritas utama, prioritas rendah dan yang berlebihan dari kepuasan customer bongkar muat barang pada Terminal Petikemas Semarang. Sampel yang digunakan sebanyak 73 responden (perusahaan) dengan analisis data menggunakan Important Performance Analysis (IPA). Berdasarkan hasil analisis diagram Kartesius diketahui bahwa faktor-faktor persyaratan pelayanan, kemampuan petugas pelayanan, kewajaran biaya pelayananan dan kepastian biaya pelayanan merupakan faktor yang dianggap penting oleh pelanggan tetapi pada kenyataannya faktor-faktor ini belum sesuai dengan harapan. Faktor-faktor mendapat perhatian lebih atau diperbaiki sehingga kinerjanya meningkat. Sedangkan faktor kejelasan petugas pelayanan, kedisiplinan petugas pelayanan, keadilan mendapatkan pelayanan dan kenyamanan lingkungan merupakan faktor yang dianggap penting telah sesuai dengan kenyataan yang dirasakan oleh pelanggan sehingga tingkat kepuasan relatif tinggi. Faktor kejelasan petugas pelayanan, kedisiplinan petugas pelayanan, keadilan mendapatkan pelayanan dan kenyamanan lingkungan harus tetap dipertahankan karena atribut-atribut inilah yang telah menarik perhatian pelanggan untuk memanfaatkan produk tersebut.
\end{abstract}

Kata-kata Kunci: Optimasi, Penjadwalan proyek.

\section{Pendahuluan}

Pelabuhan Tanjung Emas merupakan salah satu dari tiga pelabuhan besar di pantura Pulau Jawa disamping Tanjung Priok di belahan Barat dan Tanjung Perak dibagian Timur. Pelabuhan Tanjung Emas merupakan pelabuhan utama di Jawa
Tengah. Peran Pelabuhan Tanjung Emas menjadi sangat penting dan strategis, karena merupakan simpul utama perekonomian dan pintu gerbang ekspor import Provinsi Jawa Tengah.

Terminal Petikemas Semarang (TPKS) terletak di lokasi strategis di tengah-tengah pulau Jawa yang 
memberikan pelayanan jasa petikemas (container terminal handling) yang handal, aman, dan terintegrasi antar moda serta didukung dengan penggunaan teknologi informasi yang modern dan didesain untuk memenuhi kebutuhan penggunaan jasa. TPKS sangat siap terhadap persaingan dan kompetisi dengan mengusung spirit memberikan pelayanan terbaik kepada pengguna jasa dengan sepenuh hati dan dengan kebersamaan meningkatkan pelayanan PRIMA, yaitu Professional, Responsif, Inovatif, Modern dan Akuntable. Komitmen Manajemen TPKS adalah memberikan pelayanan terbaik kepada pengguna jasa dengan sepenuh hati (PT. Pelindo III, 2013)

Selama tahun 2012-2013 masih adanya keluhan dan berulang dari tahun 2012 ke 2013. Keluhan ini disampaikan oleh konsumen TPKS melalui media SMS keluhan, kartu saran/pengaduan pengguna jasa, email customer service dan surat yang disampaikan kepada manajemen TPKS. Adanya keluhan ini menandakan masih adanya kelemahan dari pelayanan yang diberikan TPKS kepada konsumennya sehingga dapat menyebabkan ketidakpuasan dari konsumen.

Pihak manajemen harus sadar akan tingginya persaingan dalam pasar globalisasi saat ini, sehingga memicu bagi pihak manajemen untuk selalu mengantisipasi dengan berbagai cara agar dapat memperoleh pangsa pasar. Dengan semakin besarnya pangsa pasar yang diperoleh maka dimungkinkan suatu perusahaan tersebut memperoleh pasar yang tinggi agar dapat terus bersaing dan melanjutkan kelangsungan usahanya. Pangsa pasar biasanya memilih produk dan jasa yang memberikan nilai terbesar bagi mereka. Jadi, kunci agar berhasil dan dapat mempertahankan pasar tersebut adalah memahami lebih baik kebutuhan dan proses pembelian mereka, termasuk didalamnya dengan memberikan mutu dan servis yang terbaik, sehingga customer merasa puas.

\section{Metodologi Penelitian}

\section{Jenis dan sumber data}

Untuk memberikan kejelasan kepada responden maka disertakan beberapa jawaban alternatif yang dapat dipilih dengan jelas. Data sekunder adalah data yang diperoleh secara tidak langsung dengan metode dokumentasi dimana memperoleh data dari kantor Terminal Petikemas Semarang, literatur dan sumber-sumber pustaka lainnya.

\section{Populasi dan sampel}

a. Populasi

Populasi dalam penelitian ini adalah pengguna (user) jasa Terminal Petikemas Semarang (TPKS) yang berjumlah 258 perusahaan.

b. Sampel

Berdasarkan rumus Slovin, diperoleh jumlah sampel sebanyak 72,07. Pada penelitian ini jumlah sampel yang digunakan sebanyak 73 responden. Teknik sampling yang digunakan adalah accidental sampling yaitu sampel yang digunakan adalah responden yang ditemui pada saat penelitian.

\section{Hasil dan Pembahasan}

\section{Penilaian hasil harapan dan kinerja}

Pada analisis ini akan digunakan ImportancePerformance Analysis untuk memperoleh tingkat kesesuaian antara kinerja layanan jasa petikemas dengan harapan responden atas layanan jasa petikemas. Dengan ketentuan bahwa kepuasan layanan Terminal Petikemas Semarang merupakan tingkat kesesuaian antara kinerja yang telah dilakukan Terminal Petikemas Semarang terhadap tingkat kepentingan/harapan pengguna jasa atau konsumen.

Di bawah ini disajikan tabel mengenai tingkat kepuasan atau kesesuaian yang dirasakan oleh pengguna layanan jasa petikemas. Tabel 1 ini akan menjelaskan besarnya kinerja dan harapan, serta tingkat kepuasan yang diterima oleh responden dalam bentuk prosentase dan asumsi perhitungan skor.

Berdasarkan Tabel 1, jika dilihat dari 14 (empat belas) indikator yang dijadikan tolak ukur dari penelitian ini, pengguna layanan jasa Terminal Petikemas Semarang sudah memuaskan.

1. Pada faktor prosedur pelayanan diketahui pelanggan merasa cukup puas atas kejelasan prosedur proses CEIR dan prosedur komplain atas pelayanan yang diberikan Terminal Petikemas Semarang.

2. Faktor Persyaratan Pelayanan, pelanggan merasa cukup puas atas persyaratan yang jelas dalam prosedur CEIR namun kurang puas terhadap indikator persyaratan yang mudah dimengerti konsumen. 
Yoeli Janto

Analisis Tingkat Kepuasan Konsumen terhadap Pelayanan Bongkar-Muat Barang pada Terminal Petikemas Semarang

Tabel 1. Skor penilaian harapan dan kinerja

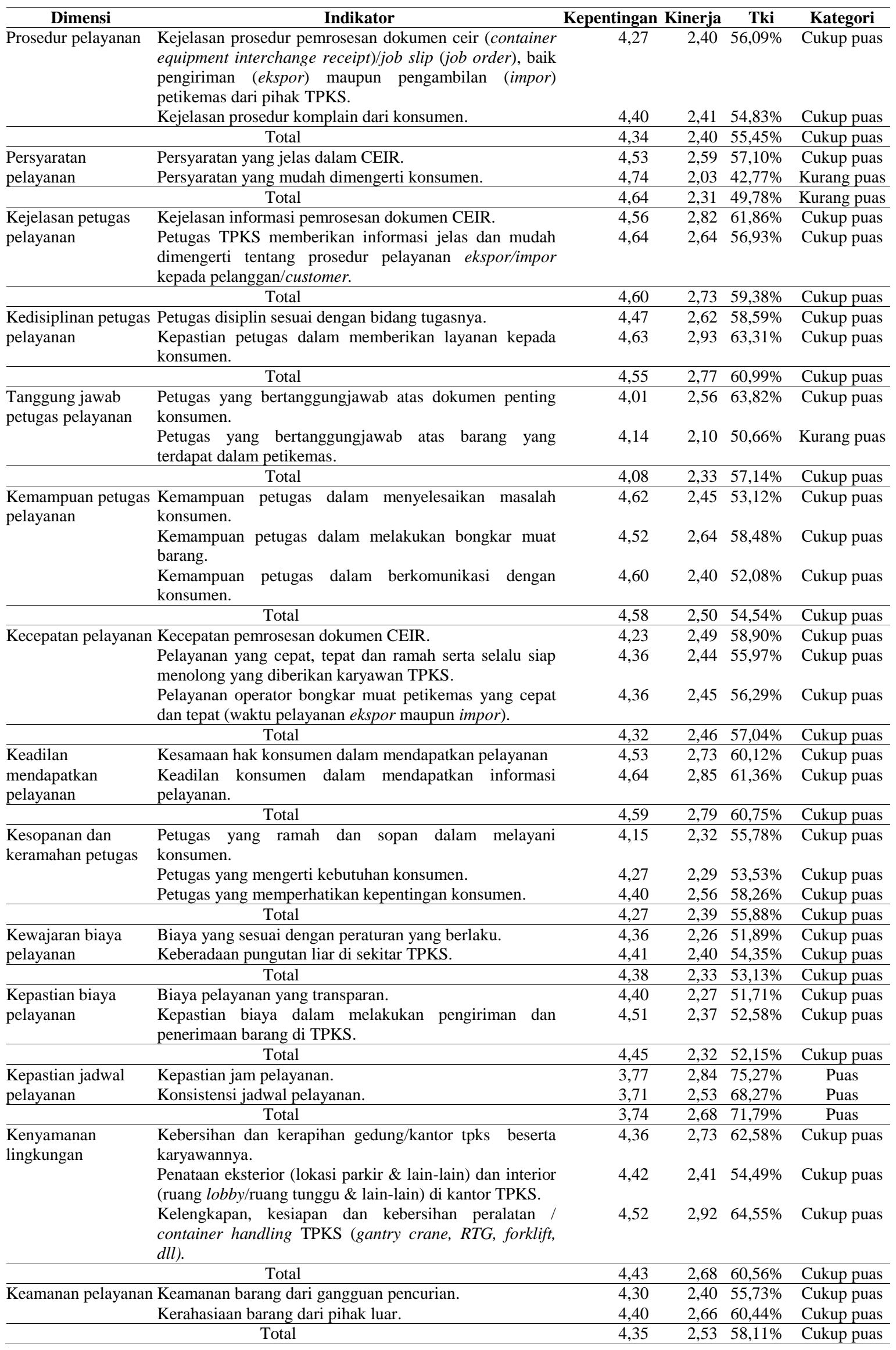


3. Faktor Kejelasan Petugas Pelayanan, pelanggan Terminal Petikemas Semarang merasa cukup puas atas pelayanan dalam kejelasan pemrosesan dokumen CEIR dan kejelasan petugas dalam memberikan informasi prosedur pelayanan ekspor/impor.

4. Pada faktor Kedisiplinan Petugas Pelayanan, pelanggan merasa cukup puas atas kedisplinan petugas pada bidang tugasnya dan kepastian petugas dalam memberikan layanan kepada konsumen.

5. Penilaian pada faktor Tanggung Jawab Petugas Pelayanan, konsumen merasa cukup puas atas tanggung jawab petugas atas dokumen penting. Namun konsumen merasa kurang puas terhadap tanggung jawab petugas atas barang yang terdapat dalam peti kemas.

6. Penilaian konsumen pada faktor Kemampuan Petugas Pelayanan, konsumen merasa cukup puas atas kemampuan petugas menyelesaikan komplain, kemampuan petugas dalam bongkar muat barang maupun kemampuan petugas dalam berkomunikasi dengan konsumen.

7. Penilaian konsumen pada faktor Kecepatan Pelayanan, konsumen merasa cukup puas atas kecepatan pemrosessan dokumen CEIR, kecepatan pelayanan dalam menolong kebutuhan konsumen dan kcepatan operator dalam bongkar muat petikemas.

8. Penilaian konsumen pada faktor Keadilan Mendapatkan Pelayanan, konsumen merasa cukup puas atas kesamaan hak konsumen dalam mendapatkan pelayanan maupun keadilan bagi konsumen dalam mendapatkan informasi pelayanan.

9. Penilaian konsumen pada faktor Kesopanan dan Keramahan Petugas, konsumen merasa cukup puas terhadap keramahan petugas dalam melayani konsumen, perhatian dan empati petugas terhadap kebutuhan konsumen.
10. Penilaian konsumen pada faktor Kewajaran Biaya Pelayanan, konsumen merasa cukup puas atas kesesuaian biaya dengan peraturan yang berlaku dan keberadaan pungutan liar di areal Terminal Petikemas Semarang.

11. Penilaian konsumen pada faktor Kepastian Biaya Pelayanan, konsumen merasa cukup puas atas transparasi biaya dan kepastian biaya dalam proses pengiriman dan penerimaan barang.

12. Penilaian konsumen pada faktor Kepastian Jadwal Pelayanan, konsumen merasa puas terhadap kepastian jam pelayanan maupun konsistensi petugas terhadap jadwal pelayanan.

13. Penilaian konsumen pada faktor Kenyamanan Lingkungan, konsumen merasa cukup puas terhadap kebersihan dan kerapihan gedung, penataan eksterior gedung maupun kelengkapan, kesiapan dan kebersihan peralatan bongkar muat.

14. Penilaian konsumen pada faktor Keamanan Pelayanan, konsumen merasa cukup puas atas keamanan barang dari gangguan pencurian maupun kerahasiaan barang dari pihak luar.

\section{Analisis tingkat kepuasan responden}

Pada analisis ini akan diuraikan mengenai kepuasan masing-masing responden. Perhitungan pada analisis ini digunakan ImportancePerformance Analysis untuk memperoleh tingkat kesesuaian antara kinerja pelayanan dengan harapan responden atas pelayanan yang diberikan.

Penghitungan tingkat kesesuaian pelanggan dilakukan dengan menggunakan rumus dibawah ini:

$\mathrm{T}_{\mathrm{ki}}=\frac{\mathrm{X}_{\mathrm{i}}}{\mathrm{Y}_{\mathrm{i}}} \times 100 \%$

Berikut akan disajikan tingkat kepuasan masingmasing responden pengguna layanan jasa Terminal Petikemas Semarang:

Tabel 2. Tingkat kepuasan masing-masing indikator

\begin{tabular}{|c|c|c|c|c|c|}
\hline No & Dimensi & Kepentingan & Kinerja & TKI & Kategori \\
\hline 1 & Prosedur pelayanan & 4,34 & 2,40 & $55,45 \%$ & Cukup puas \\
\hline 2 & Persyaratan pelayanan & 4,64 & 2,31 & $49,78 \%$ & Kurang puas \\
\hline 3 & Kejelasan petugas pelayanan & 4,60 & 2,73 & $59,38 \%$ & Cukup puas \\
\hline 4 & Kedisiplinan petugas pelayanan & 4,55 & 2,77 & $60,99 \%$ & Cukup puas \\
\hline 5 & Tanggungjawab petugas pelayanan & 4,08 & 2,33 & $57,14 \%$ & Cukup puas \\
\hline 6 & Kemampuan petugas pelayanan & 4,58 & 2,50 & $54,54 \%$ & Cukup puas \\
\hline 9 & Kesopanan dan keramahan petugas & 4,27 & 2,39 & $55,88 \%$ & Cukup puas \\
\hline 10 & Kewajaran biaya pelayanan & 4,38 & 2,33 & $53,13 \%$ & Cukup puas \\
\hline 11 & Kepastian biaya pelayanan & 4,45 & 2,32 & $52,15 \%$ & Cukup puas \\
\hline 12 & Kepastian jadwal pelayanan & 3,74 & 2,68 & $71,79 \%$ & Puas \\
\hline 13 & Kenyamanan lingkungan & 4,43 & 2,68 & $60,56 \%$ & Cukup puas \\
\hline
\end{tabular}


Berdasarkan tabel di atas, dapat diketahui bahwa dari dari 14 (empat belas) faktor yang digunakan untuk mengukur kinerja jasa layanan Terminal Petikemas Semarang diketahui bahwa secara umum pelanggan sudah merasa cukup puas dengan kinerja layanan yang dilakukan perusahaan Terminal Petikemas Semarang.

Selanjutnya dari perhitungan tingkat kesesuaian konsumen diatas akan dianalisis menggunakan diagram Kartesius. Diagram Kartesius bertujuan untuk menilai seluruh dimensi kinerja perusahaan jasa layanan pelayanan Terminal Petikemas Semarang berdasarkan harapan konsumen. Adanya diagram juga akan dapat menentukan posisi masing-masing dimensi pelayanan sehingga dapat diketahui strategi pelayanan atau kinerja yang harus dijalankan oleh Terminal Petikemas Semarang dimasa yang akan datang.

Gambar 1 adalah diagram Kartesius untuk setiap item pertanyaan yang digunakan dalam mengukur tingkat kepuasan pengguna jasa Terminal Petikemas Semarang:

Pada Gambar 1 tersebut dapat dilihat bahwa unsurunsur pelaksanaan kinerja/pelayanan yang menyebabkan kepuasan pengguna jasa Terminal Petikemas Semarang terbagi menjadi empat bagian. Masing-masing variabel pada keempat kuadaran tersebut dapat dijelaskan pada Gambar 1.

\section{Kuadran A}

Pada kuadran ini ditunjukkan faktor-faktor yang dianggap penting oleh pelanggan tetapi pada kenyataannya faktor-faktor ini belum sesuai dengan harapan. Atribut-atribut yang termasuk kedalam kuadran ini harus mendapat perhatian lebih atau diperbaiki sehingga kinerjanya meningkat. Faktor-faktor atau indikator-indikator kinerja yang masuk ke dalam kuadran ini adalah:

a. persyaratan pelayanan,

b. kemampuan petugas pelayanan,

c. kewajaran biaya pelayananan,

d. kepastian biaya pelayanan.

\section{Kuadran B}

Kuadran ini menunjukkan faktor-faktor yang dianggap penting telah sesuai dengan kenyataan yang dirasakan oleh pelanggan sehingga tingkat kepuasan relatif tinggi. Atribut-atribut yang termasuk ke dalam kuadran ini harus tetap dipertahankan karena atribut-atribut ini telah menarik perhatian pelanggan untuk memanfaatkan produk tersebut. Faktor-faktor kinerja yang masuk ke dalam kuadran ini adalah:
a. kejelasan petugas pelayanan
b. kedisiplinan petugas pelayanan
c. keadilan mendapatkan pelayanan
d. kenyamanan lingkungan

3. Kuadran C

Kuadran ini menunjukkan faktor-faktor yang dianggap kurang penting oleh pelanggan dan pada kenyataannya tidak terlalu istimewa. Peningkatan pada atribut-atribut dalam kuadran ini dapat dipertimbangkan kembali karena pengaruh terhadap manfaat yang dirasakan oleh pelanggan sangat kecil. Faktor-faktor atau indikator-indikator kinerja yang termasuk dalam kuadran ini adalah:
a. prosedur pelayanan
b. tanggungjawab petugas pelayanan
c. kecepatan pelayanan
d. kesopanan dan keramahan petugas

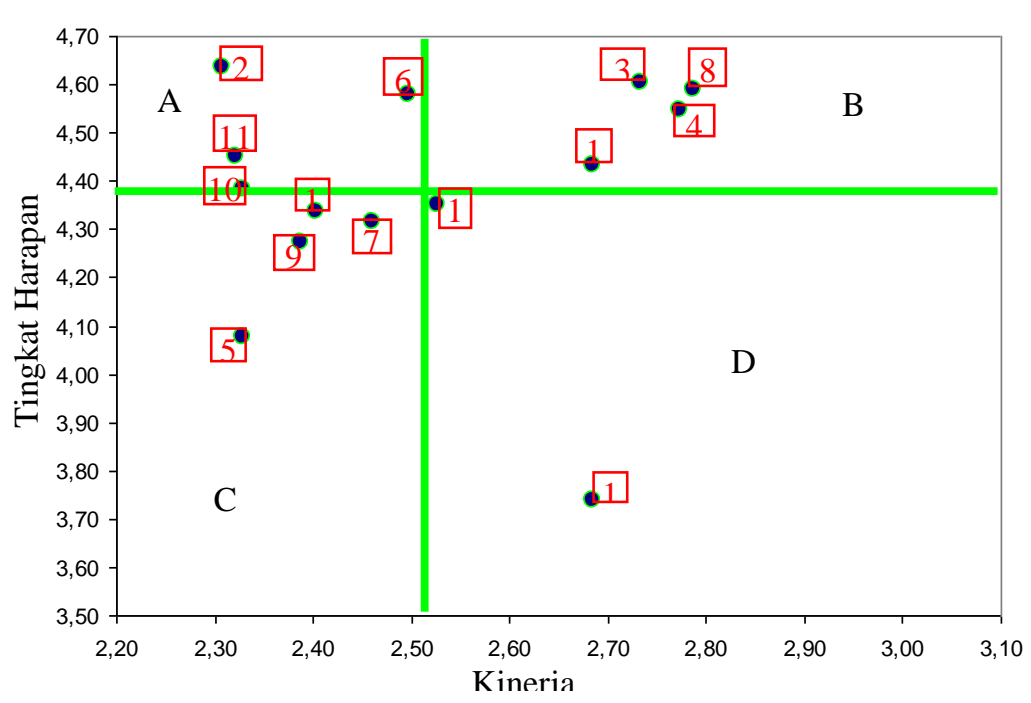

Gambar 1. Diagram Kartesius
Keterangan:

1. Prosedur pelayanan

2. Persyaratan pelayanan

3. Kejelasan petugas pelayanan

4. Kedisiplinan petugas pelayanan

5. Tanggung jawab petugas pelayanan

6. Kemampuan petugas pelayanan

7. Kecepatan pelayanan

8. Keadilan mendapatkan pelayanan

9. Kesopanan dan keramahan petugas

10. Kewajaran biaya pelayanan

11. Kepastian biaya pelayanan

12. Kepastian jadwal pelayanan

13. Kenyamanan lingkungan

14. Keamanan pelayanan 
4. Kuadran D

Kuadran ini menunjukkan faktor-faktor yang dianggap kurang penting oleh pelanggan namun pada kenyataannya sudah cukup memuaskan. Faktor-faktor atau indikatorindikator kinerja yang termasuk dalam kuadran ini adalah:

a. kepastian jadwal pelayanan

b. keamanan pelayanan

Berdasarkan hasil penilaian pada diagram Kartesius terlihat bahwa aspek persyaratan pelayanan, kemampuan petugas pelayanan, kewajaran biaya pelayananan dan kepastian biaya pelayanan. masih jauh di bawah harapan para pengguna jasa Terminal Petikemas Semarang. Kinerja pelayanan Terminal Petikemas Semarang merupakan alat ukur dalam menentukan tingkat pencapaian keberhasilan kinerja perusahaan dalam memberikan layanan kepada konsumennya yang merupakan alat untuk mengetahui dampak dari suatu kebijakan yang telah dilakukan serta terciptanya pelayanan Terminal Petikemas Semarang yang efektif dan efisien.

Kepuasan pelanggan Terminal Petikemas Semarang adalah tingkat perasaan yang timbul antara harapan dan layanan yang diterima tingkat kepuasaan merupakan fungsi dari perbedaan antara kinerja yang dirasakan dengan harapan. Apabila kinerja di bawah harapan, maka pelanggan akan kecewa, bila kinerja sesuai dengan harapan, pelanggan akan puas, sedangkan jika kinerja melebihi harapan, pelanggan akan sangat puas. Kepuasan pelanggan Terminal Petikemas Semarang merupakan tingkat yang dirasakan pelanggan sebagai hasil perbandingan antara kinerja aktual produk (perceived peformance) dengan harapan pelanggan (respon expectations). Dari definisi ini, dapat ditarik kesimpulan bahwa pada dasarnya pengertian kepuasaan pelanggan mencakup perbedaan antara harapan dengan kinerja atau hasil yang dirasakan. Dengan kata lain, kepuasaan pelanggan adalah sejauh mana anggapan kinerja produk memenuhi harapan pelanggan. Bila yang diterima sama atau bahkan lebih dari harapannya, maka pelanggan akan puas. Untuk itu perbaikan dalam aspek persyaratan pelayanan, kemampuan petugas pelayanan, kewajaran biaya pelayananan dan kepastian biaya pelayanan segera dilaksanakan. Hal ini disebabkan pelanggan merasa aspek tersebut adalah aspek yang memiliki kinerja yang jauh dari harapan pelanggan.

Menurut Gerson (2002) kepuasan pelanggan adalah salah satu isu yang paling penting dalam organisasi dari semua jenis bisnis, yang dibenarkan oleh filosofi orientasi-pelanggan dan prinsip- prinsip utama perbaikan terus-menerus dalam perusahaan modern. Untuk alasan ini, kepuasan pelanggan harus diukur dan diterjemahkan ke dalam sejumlah parameter terukur. Pengukuran kepuasan pelanggan dapat dianggap sebagai feedback system yang dapat paling diandalkan, mengingat bahwa feedback system menyediakan secara efektif, langsung dan bermakna sebagai harapan dan tujuan preferensi klien. Sementara Oliver (2003) menyatakan kepuasan adalah tanggapan pelanggan atas terpenuhinya kebutuhan, yang berarti bahwa penilaian pelanggan atas barang atau jasa memberikan tingkat kenyamanan dengan pemenuhan suatu kebutuhan, termasuk pemenuhan kebutuhan yang tidak sesuai harapan atau pemenuhan yang melebihi harapan pelanggan.

Dipertegas oleh Kotler (2004) yang menyatakan bahwa kepuasan pelanggan yaitu tingkatan dimana anggapan kinerja (perceived performance) produk akan sesuai dengan harapan seorang pelanggan. Bila kinerja produk jauh lebih rendah dibandingkan harapan pelanggan, pembelinya tidak puas. Sebaliknya bila kinerja sesuai dengan harapan atau melebihi harapan, pembelinya merasa puas atau merasa puas atau merasa amat gembira. Seiring dengan pendapat diatas, Purnomo (2003) mengartikan kepuasan pelanggan sebagai perbedaan antara harapan dan kinerja atau hasil yang diharapkan maksudnya bahwa kepuasan pelanggan tercipta jika pelanggan merasakan output atau hasil pekerjaan sesuai dengan harapan, atau bahkan melebihi harapan pelanggan.

Ukuran keberhasilan penyelenggaraan pelayanan ditentukan oleh tingkat kepuasan penerima pelayanan. Kepuasan penerima pelayanan dicapai apabila penerima pelayanan memperoleh pelayanan sesuai dengan yang dibutuhkan dan diharapkan. Dengan berpedoman pada hal itu, diharapkan Terminal Petikemas Semarang sebagai salah satu penyelenggara pelayanan publik, dalam hal ini manajemen yang dalam pelaksanaan tugasnya senantiasa bersinggungan langsung dengan konsumen, hendaknya senantiasa mencari feed back atau membuka diri dengan segala kritik guna mengevaluasi diri terhadap bentuk pelayanan yang sudah dilakukan, untuk selanjutnya memperbaiki diri dan mencari solusi untuk perbaikan pelayanan lebih lanjut.

Pada penelitian Hermanto (2008) yang berjudul Analisa Tingkat Kepuasan Konsumen Terhadap Pelayanan Terminal Petikemas Semarang, disimpulkan bahwa faktor-faktor yang pelaksanaannya dilakukan dengan sangat baik oleh perusahaan, namun dinilai kurang penting oleh pelanggan sehingga terkesan berlebihan, menurut pengguna jasa ekspor barang tidak ada, sedangkan 
menurut pengguna jasa impor barang masih ada, yaitu: kebersihan dan kerapihan gedung/kantor TPKS beserta karyawannya serta faktor penataan eksterior (lokasi parkir, \& lain-lain) dan interior (ruang lobby/ruang tunggu \& lain-lain) di kantor TPKS. Sedangkan pada penelitian ini, faktor tersebut termasuk dalam dimensi kenyamaan yang telah mengalami peningkatan menjadi aspek yang dianggap penting oleh pelanggan dan kinerja pelayanannya telah sesuai dengan harapan pelanggan. Hal ini berarti manajemen Terminal Petikemas Semarang telah melakukan perbaikan pada aspek tersebut sehingga mengalami peningkatan kepuasan pelanggan pada aspek tersebut.

Hasil lain pada penelitian Hermanto (2008) menunjukkan faktor-faktor atau atribut yang mempengaruhi kepuasan pelanggan TPKS berada dalam kuadran B ini perlu dipertahankan, karena pada umumnya tingkat pelaksanaannya telah sesuai dengan kepentingan dan harapan pelanggan, sehingga dapat memuaskan pelanggan/customers. Faktor-faktor yang termasuk dalam kuadran B ini adalah: kelengkapan, kesiapan dan kebersihan peralatan/container handling TPKS (gantry crane, RTG, forklift, dll), Kecepatan pemrosesan dokumen CEIR (Container Equipment Interchange Receipt)/job slip (job order), baik pengiriman (ekspor) maupun pengambilan (impor) petikemas dari pihak TPKS, pelayanan operator bongkar muat petikemas yang cepat dan tepat (waktu pelayanan ekspor maupun impor) dan pengetahuan dan kecakapan teller maupun customer service officers (CSO) dari pihak TPKS. Pada penelitian ini, aspek kecepatan pelayanan masuk dalam kuadran yang prioritas rendah. Sedangkan kemampuan pegawai dalam memberikan pelayanan termasuk dalam kuadran prioritas utama. Berdasarkan kedua hasil penelitian tersebut diketahui bahwa terjadi penurunan kinerja pelayanan pada kemampuan pegawai, dimana pada penelitian Hermanto (2008) aspek tersebut masuk dalam kuadran yang harus dipertahankan, sedangkan pada penelitian ini masuk dalam kudran prioritas utama. Hal ini berarti bahwa adanya penurunan kinerja pelayanan pada aspek kemampuan pegawai dalam memberikan pelayananan kepada pelanggan.

Hasil penelitian ini serupa dengan hasil penelitian yang dilakukan oleh Hermanto (2008) yang berjudul Analisa Tingkat Kepuasan Konsumen Terhadap Pelayanan Terminal Petikemas Semarang. Pada penelitian tersebut disimpulkan bahwa faktor yang terdapat dalam kuadran A yang berarti aspek tersebut masih jauh di bawah harapan para pengguna jasa Terminal Petikemas Semarang. Kinerja pelayanan Terminal Petikemas Semarang adalah pelayanan yang cepat, tepat dan ramah serta selalu siap menolong yang diberikan karyawan TPKS dan kemampuan karyawan TPKS untuk cepat tanggap dalam menghadapi keluhan/masalah yang timbul dari customer/pengguna jasa.

Pada aspek persyaratan pelayanan, manajemen Terminal Petikemas Semarang segera mengevaluasi persyaratan pelayanan yang wajib dipenuhi oleh pelanggan. Sosialisasi terhadap persyaratan pelayanan yang harus dipenuhi oleh pelanggan sangat diperlukan agar pelanggan dapat mengetahui dan memahami persyaratan yang harus dipenuhi oleh pelanggan. Perbaikan yang dapat dilakukuan pada aspek kemampuan petugas pelayanan, adalah dengan meningkatkan kemampuan pegawai dalam memberikan pelayanan kepada pelanggan. Manajemen Terminal Petikemas Semarang perlu memberikan pelatihan dan kursus kepada pegawainya dalam memberikan layanan kepada pelanggan.

Pada aspek kewajaran biaya adalah aspek yang sangat diperhatikan oleh pelanggan. Hal ini disebabkan pada aspek ini sangat rentan dengan adanya pungutan liar yang terjadi di seputar pelayanan Terminal Petikemas Semarang. Manajemen Terminal Petikemas Semarang perlu transparan kepada pelanggan mengenai biaya yang dibebankan oleh manajemen kepada pelanggan. Selain itu juga, manajemen Terminal Petikemas Semarang harus tegas kepada pegawai yang membebankan biaya tambahan diluar prosedur kepada pelanggan. Untuk menjaga kewajaran biaya pelayanan, manajemen Terminal Petikemas Semarang juga harus menghapus adanya praktek percaloan yang terjadi dalam pelayanannya. Pada aspek kepastian biaya pelayanan adalah aspek yang paling rawan terjadinya pungutan liar dalam proses layanan di Terminal Petikemas Semarang. Manajemen Terminal Petikemas Semarang perlu tegas terhadap pungutan liar yang terjadi di areal pelayanan Terminal Petikemas Semarang.

Evaluasi dan perbaikan yang dilakukan oleh manajemen Terminal Petikemas Semarang dalam aspek-aspek yang jauh dari harapan konsumen dimaksudkan agar terpenuhinya harapan pelanggan di masa yang akan datang. Komplain yang terjadi pada manajemen Terminal Petikemas Semarang selama tahun 2012-2013 yang disampaikan melalui media SMS keluhan, kartu saran/pengaduan pengguna jasa, email customer service dan surat diusahakan tidak akan terjadi lagi. Hal ini disebabkan manajemen Terminal Petikemas Semarang akan lebih tanggap terhadap aspek-aspek yang menjadi perhatian pelanggan dalam mendapatkan pelayanan di Terminal Petikemas Semarang. 


\section{Kesimpulan}

Setelah melakukan analisis kinerja dan harapan pengguna jasa Terminal Petikemas Semarang, maka kesimpulan yang diperoleh adalah sebagai berikut:

1. Pengguna jasa Terminal Petikemas Semarang pada merasa puas pada faktor kepastian jadwal pelayanan. Sedangkan yang masuk dalam kategori cukup puas terdapat pada faktor prosedur pelayanan, persyaratan pelayanan, kejelasan petugas pelayanan, kedisiplinan petugas pelayanan, tanggung jawab petugas pelayanan, kemampuan petugas pelayanan, kecepatan pelayanan, keadilan mendapatkan pelayanan, kesopanan dan keramahan petugas, kewajaran biaya pelayanan, kepastian biaya pelayanan, kenyamanan lingkungan dan keamanan pelayanan.

2. Berdasarkan analisis diagram Kartesius diketahui bahwa faktor-faktor persyaratan pelayanan, kemampuan petugas pelayanan, kewajaran biaya pelayananan dan kepastian biaya pelayanan merupakan faktor yang dianggap penting oleh pelanggan tetapi pada kenyataannya faktor-faktor ini belum sesuai dengan harapan. Faktor-faktor mendapat perhatian lebih atau diperbaiki sehingga kinerjanya meningkat. Sedangkan faktor kejelasan petugas pelayanan, kedisiplinan petugas pelayanan, keadilan mendapatkan pelayanan dan kenyamanan lingkungan merupakan faktor yang dianggap penting telah sesuai dengan kenyataan yang dirasakan oleh pelanggan sehingga tingkat kepuasan relatif tinggi. Faktor kejelasan petugas pelayanan, kedisiplinan petugas pelayanan, keadilan mendapatkan pelayanan dan kenyamanan lingkungan harus tetap dipertahankan karena atribut-atribut inilah yang telah menarik perhatian pelanggan untuk memanfaatkan produk tersebut.

\section{Saran}

Saran yang dapat disampaikan setelah melakukan penelitian tentang kepuasan pengguna jasa Terminal Petikemas Semarang adalah sebagai berikut:

1. Aspek persyaratan pelayanan, kemampuan petugas pelayanan, kewajaran biaya pelayananan, dan kepastian biaya pelayanan adalah aspek yang menjadi prioritas utama dalam meningkatkan kepuasan pelanggan. usaha yang dapat dilakukan oleh manajemen Terminal Petikemas Semarang adalah: a. Melakukan sosialisasi terhadap persyaratanpersyaratan wajib yang harus dipenuhi oleh pelanggan dalam melakukan pengiriman dan penerimaan petikemas baik dari maupun luar negeri.

b. Memberikan pendidikan dan pelatihan khusus kepada karyawannya dalam memberikan pelayanan kepada pelanggannya

c. Meningkatkan kemampuan karyawan terutama dalam bongkar muat barang, karena dianggap karyawan yang ada kurang memenuhi harapan pelanggan.

d. Tegas kepada pegawai yang membebankan biaya tambahan diluar ketentuan manajamen kepada pelanggan

e. Menghapus dan mencegah timbulnya praktek percaloan dalam pelayanan Terminal Petikemas Semarang.

f. Perlu sosialisasi kepada pelanggan besarnya biaya yang dibebankan kepada pelanggan pada setiap tahapan pelayanan di Terminal Petikemas Semarang.

g. Melarang setiap pegawainya untuk menerima biaya tambahan untuk kepentingan pribadi.

2. Manajemen Terminal Petikemas Semarang perlu membuat standar/tolok ukur, misal standar waktu dalam setiap proses pelayanan yang diberikan kepada pelanggan. Adanya standar waktu pelayanan dapat meningkatkan transparansi pelayanan yang diberikan kepada pelanggan.

\section{Daftar Pustaka}

Aprilia, M., 2011. Evaluasi terhadap Kualitas Pelayanan Publik Melalui Kajian Indeks Kepuasan Masyarakat (IKM) pada Unit Referensi UPU Perpustakaan Universitas Gadjah Mada, Tesis Magister Ilmu Administrasi Universitas Diponegoro, Yogyakarta.

Brandt, K., 2010. Great Expectations Assortment Size, Expectations, and Satisfaction, Journal of Marketing Research Vol. XLVII (April 2010), 312322, American Marketing Association.

Fornel, C., 1992. Source and Outcomes of Competitive Advantage: An Exploratory Study in the Furniture Industry, Decision Sciences 25 (5/6): $669-689$

Gerson, A., and Mohammed M., 2002. Exploring the effect of self-image congruence and brand preference on satisfaction: the role of expertise, Journal Of Marketing Management 2007, Vol. 23, No. 7-8, pp. 613-629. 
Gerson, R., 2002. Service quality, relationship satisfaction, trust, commitment and business-tobusiness loyalty, Journal of Commerce 2002.

Ghozali, I., 2006. Aplikasi Analisis Multivariate dengan Program SPSS, RPUD Semarang.

Handajani, M., 2004. Analisis Kinerja Opreasional Bongkar Muat Petikemas Pelabuhan Tanjung Emas, Jurnal Transportasi Volume 4 Tahun I Juni 2004. Hal. $1-12$.

Hermanto, Andi W., 2008. Analisa Tingkat Kepuasan Konsumen terhadap Pelayan Terminal Petikemas Semarang, Tesis Universitas Diponegoro, Semarang.

Irawan, H., 2003. Analisis Kepuasan Konsumen dalam Penggunaan Jasa Internet, Jurnal Ekonomi dan Bisnis Indonesia 13 (3): 70 - 79.

J., Supranto, 2007. Manajemen Pemasaran Modern, Liberty, Yogyakarta.

Jamaludin, A., 1989. Teknik Skala Penyusunan dan Skala Pengukuran, PPK Universitas Gadjah Mada, Yogjakarta.

Jusmin, N., 2003. Analisa Tingkat Kepuasan Penumpang terhadap Kinerja Pengemudi Angkutan Mikrolet (Studi Kasus di Jl. Urip Sumohardjo Makasar). Tesis Program Pasca Sarjana Universitas Hasanudin, Makasar.

Koleangan, D., 2008. Sistim Petikemas (Container System), Rineka Cipta, Jakarta.

Kotler, P., dan Kevin Lane, K., 2007, Manajemen Pemasaran, Edisi Kedua Belas, Indeks, Jakarta.

Kotler, P., 2004. Manajemen Pemasaran, Analisis Perencanaan, Implementasi, dan Pengendalian, Salemba Empat, Jakarta.

Kramadibrata, S., 2002. Perencanaan Pelabuhan, Institut Teknologi Bandung, Bandung.

Lupiyadi, R., 2001. Statistik Induktif edisi keempat BPFE Yogyakarta.

Martila, J., Paul and Jerry C., James., 1977. Consumer Behaviour and Marketing Strategy, Homewood, Illinois: Richard D. Irwin Incorporation.

Martinez , Jose M., Hurtado, 2003. Exploring Paths Between Web Adoption And firm Performance: The Mediating Effect Of Customer Satisfaction, Corporate Image, Market Expansion
And Internal Efficiency, Total Quality Management Vol. 20, No. 10, October 2009.

Nasir, Moch., 2003. Methode penelitian, Ghalia Indonesia, Jakarta.

Oliver, D., H., 2003. Total Quality Service, Principle, Practices, and Implimentation, Delray Beachm St. Lucie Press.

Parasuraman, A., and Bery Z., 1996. The Behavioral Consequences of Service Quality, Journal of Marketing, Vol 60, p. 31-46.

Pasurahman, A., dan Valeire A. Zeithaml., 2001, SERVQUAL : A Multiple-Item Scale for Measuring Consumer Persception of service Quality, Journal of Retailing, Vol 64, Number 1, spring, 12-4.

Pelabuhan Indonesia III, PT., 2013. Sistem dan Prosedur Pelayanan Jasa Petikemas, Terminal Peti Kemas Semarang, Semarang.

Peraturan Pemerintah RI No.69 Tahun 2001. Pelabuhan dan Fungsi Serta Penyelengaraannya.

Purnomo, B., 2003. Pengukuran Tingkat Kepuasan Pelanggan, Studi kasus di Perusahaan Penerbangan " $X$ ", Tesis Magister Manajemen Universitas Diponegoro, Tidak dipublikasikan.

Semedi, B., 2012. Indicator Penyalahgunaan Petikemas, Pusdiklat Bea dan Cukai.

Siswadi, 2005. Kajian Kinerja Peralatan Bongkar Muat Petikemas di Terminal Petikemas Semarang, Tesis, Universitas Diponegoro, Semarang.

Sugiyono, 2005. Statistik Untuk Penelitian, Jakarta, Alfa Beta, Bandung.

Supranto, J., 2005. Metode Riset, Rineka Cipta, Jakarta.

Suranto, 2004. Maritim dan Pelabuhan, Andy, Yogyakarta.

Tjiptono, F., 2005. Manajemen Jasa, Andi, Yogyakarta.

Triatmodjo, B., 2009. Perencanaan Pelabuhan, Beta Offset, Yogyakarta.

Trihendradi, C., 2011. Langkah Mudah Melakukan Analisis Statistik menggunakan SPSS 19, Andi, Yogyakarta. 
Widyaguna, S., 2010. Analisa Pelayanan PT APL Indonesia dalam Persaingan Angkutan Petikemas, Skripsi, Universitas Trisakti, Jakarta.
Zeithaml, Valeire A., Leonard L. Berry, and Pasurahman, 1988. Comunication and Control Processes in the Delivery of Service Quality, Journal Marketing, April, pp. 35-38. 